\title{
Efficacy in Action: Mobilising Community Participation for Inclusive Urban Development
}

\author{
Wayne Shand ${ }^{1}$ (D)
}

Published online: 24 November 2017

(C) The Author(s) 2017. This article is an open access publication

\begin{abstract}
The idea of inclusive development rides high on the international agenda, following publication of the Sustainable Development Goals in September 2015 and the Habitat III New Urban Agenda in 2016. The commitment to 'leave no one behind' in tackling the linked challenges of economic, social and environmental development provides an encompassing statement of intent. However, it also raises a number of important questions about how ideas of inclusivity are translated into practice, in contexts where there are extreme imbalances in resource and power and where established structures of governance marginalise the involvement of the poor in the delivery of development. Drawing on a case study of a SDI affiliate organisations in Harare, Zimbabwe, this paper examines the creation of efficacy among low-income community members as a foundation for inclusive urban development. The case study is used to discuss the importance of building efficacy as a necessary condition for communities to engage in development.
\end{abstract}

Keywords Inclusive development · Efficacy $\cdot$ Low income communities · SDI · Zimbabwe

\section{Introduction}

In both the language and the targets of the Sustainable Development Goals (SDGs), inclusion is emphasised as a principal characteristic of 'doing' development and as an intended outcome. The Declaration of the UN accompanying the publication of the 17 SDGs, underlines the importance of shaping national delivery arrangements to maximise opportunities for citizens to participate in decision making, as well as

Wayne Shand

wayne.shand@manchester.ac.uk

1 Global Development Institute, University of Manchester, Arthur Lewis Building, Oxford Road, Manchester, UK 
ultimately benefitting from development activity (UN 2015). The forms of engagement articulated in the SDG targets prioritise institutional mechanisms of participation, such as the structured involvement of civil society in urban planning and management. However, the SDGs are weak on identifying the additional support needed to enable the poorest and most marginalised to overcome established structures of exclusion, in order to be involved in the delivery of the SDGs (Gupta et al. 2014). Parnell (2016) discussing the new urban target (SDG 11) notes the significance of a focus on cities, but points to the substantial task of forging the new institutional processes needed to successfully deliver ambitious goals. Realising inclusive approaches to development is far more than merely expanding the number of invited spaces of participation, it is fundamentally reconsidering how communities meaningfully become actors and contributors to the challenge of delivering sustainable development (Cornwall 2004).

The idea of 'inclusive development' promises a particular form of participation that emphasises the equal distribution of benefits among populations, regardless of individual circumstances (Rauniyar and Kanbur 2010). Beyond outcomes, inclusion also has institutional dimensions and implies the removal of barriers to enable excluded sections of society to take part in decision making and governance (Ali and Son 2007). Hickey (2013: 4) connects both of these aspects, focusing on the politics of inclusion as relational and concerned with the "workings of societies rather than the characteristics of particular groups'. Amartya Sen (1999: 53) argues that people have to be actively involved in order to shape 'their own destiny and not just as passive recipients of the fruits of cunning development programs'. Inclusive development requires structures that allow for the active participation of low income communities, who in turn need to adapt to new roles and contribute to development in ways that may be at odds with the reality of exclusionary power structures.

When applied to conditions found in many cities across the global South, there is a significant gap between the aspirations implied by 'inclusion' and the ability of organised communities to engage in the politicised and bureaucratic policy and delivery arrangements that often characterise development. Limitations arise across different domains that include the ready threat of violence by elites to prevent interference in existing structures of power (Bracking 2005; North et al. 2013) and the constraints inherent in being poor, where a lack of time, resource and access to decision making processes restrict participation to potentially exploitative forms of clientelism (Mitlin 2014). Inclusion is also shaped by scalar politics of urban governance, where dominant processes and structures determine the potential spaces of participation and interaction between communities and state organisations (MacKinnon 2010). Hickey and Du Toit (2007) provide an important reminder that 'inclusion' is not a uniformly positive outcome for people in poverty, when it is offered on adverse terms that anchor myriad forms of disempowerment. As Du Toit (2004) suggests, inclusion is not so much the opposite of exclusion, than a process of reformation, where both government and communities must construct new behaviours and outlooks to identify and overcome embedded barriers to collaborative working.

Of interest here is the ability of the poorest urban residents to be actors in, and affect the design and delivery of, development programmes. The efficacy of poor communities, as partners in inclusive development, relies on building confidence among the poor that they have a legitimate and authoritative role to play and their contributions will lead to positive benefits. The form of citizen engagement may vary considerably across 
contexts along with the type of outcomes generated, as shown by Gaventa and Barrett (2010), but are founded upon a disposition to act. The meaning of efficacy within a context of urban development, explored in this paper, reflects a human ability 'to transcend the dictates of their immediate environment and to shape and regulate the present to fit a desired future' (Bandura 2001: 7). In keeping with the ambitions of the SDGs, efficacy suggests the need to shift limiting outlooks, in a Freirean sense, in order for people to imagine and contribute to the realising of new possibilities. Efficacy operating as a collective sphere of social activity is generated and reproduced through processes of engagement, problem solving and the action of shaping lived environments. More than the operation of agency, efficacy is an enabling condition: a firm belief in the world as makeable.

This paper explores the creation of efficacy as a precondition for and component of inclusive development, through a case study of community-led action in Harare, Zimbabwe. Focusing on the work of the Zimbabwe Homeless People's Federation and their NGO partner, Dialogue on Shelter Trust, the paper considers the mechanics and the significance of building community efficacy for delivering development. The paper proceeds next with a discussion of efficacy as a form of mobilised collective action, before presenting the case study. Contextualising community-based efforts within the political economy of Zimbabwe, the paper examines the processes and challenges of building community confidence to act and then turns to the modalities of collective action. The paper concludes by discussing some implications for development policy.

\section{Poverty, Efficacy and Mobilising Collective Action}

The multi-layered realities of poverty and exclusion diminish feelings of empowerment; heightening a sense of risk associated with engaging in processes of development (Pieterse 2008). The conditions of poverty are isolating for individuals and families (Patel and Mitlin 2004) working to secure 'provisional livelihoods' (Simone 2010: 19) in urban settings. The lack of housing tenure, unstable employment and income, possibility of violence and a disconnection from sources of state provided services and protection of rights undermines individual agency, aspiration and the potential for action (Appadurai 2001, 2004; Satterthwaite and Mitlin 2014). Being poor can have severe psychological impacts, causing increased vulnerability to ill-heath and chronic poverty (Hulme and Shepherd 2003) and effecting wellbeing and self-esteem, resulting in a sense of powerlessness to control the future (Prowse 2003). Aliber (2001: 27), discussing South Africa, describes the condition of being poor as one of resignation to 'the low probability of ever escaping poverty' and 'discouraging people from taking steps to increase their chances of living a more rewarding life'.

In this context, expectations that people in poverty can easily contribute to inclusive development seems unlikely. Cleaver (2007: 240) underlines the importance of efficacy, as the firm belief that actions will lead to a positive outcomes, as a necessary condition for individual agency: 'for potential courses of action to become real, they must be both materially possible and be conceived by the agent to be within the bounds of possibility' (emphasis in original). Building the belief of individuals that they can affect the world around them, through participation in collective action, is essential to 
establishing sufficient incentive to counteract the negative consequences of poverty. Bandura (2000: 75) states ' $[\mathrm{u}]$ nless people believe that they can produce desired effects and forestall undesired ones by their actions, they have little incentive to act.' For the poorest members of society, prevailing economic and institutional conditions act as a bulwark against challenging the operation of power, particularly where stepping outside of normative social roles can have severe negative consequences.

The notion of efficacy shares common ground with more familiar concepts in development, such as capability, empowerment and agency, but provides a particular focus on how individuals feel about moving beyond the familiar. When used to examine the mechanics of inclusive development, efficacy describes the willingness of people to participate in processes that may challenge prevailing structures of power, often manifest through mundane social and bureaucratic controls, to improve their environment or wellbeing. Efficacy is the formative element of having agency or being empowered that determines the initial thoughts and steps that make engaging in new and uncertain actions possible. While the form and quality of outcome from citizen engagement in development can vary widely across contexts according to Gaventa and Barrett (2010), willingness to take a first step into new arena is difficult as active and effective citizens do not emerge automatically. Participation requires nurturing to have a positive impact on development and democratic outcomes.

Across the global South network groups including SDI (formerly Shack/Slum Dwellers International) and the Asian Coalition for Housing Rights (ACHR) work with grassroots organisations to connect with and mobilise residents of low income and informal urban settlements to involve individuals in collective action. The process of mobilisation is about creating efficacy, realised through building trust, social structures of mutual support and collaborative projects of development. To foreground the case study presented later in this paper, the processes of mobilisation employed by SDI are now elaborated to highlight the methods of community engagement that lead to inclusive forms of collective action.

\section{Rituals and Mutual Reliance}

SDI was established in 1996 as a transnational network to connect and support grassroots organisations of people (a majority of whom are women) living in informal and low income urban settlements to engage in development. Working through national affiliate members, SDI encourages community-led action to address a lack of shelter, basic service provision and insecure land tenure. The SDI model focuses on the mobilisation of households, through the creation of local savings groups, as a means to build social capital and establish dialogue within communities and between communities and city and national government on development issues. Membership of SDI extends across 32 countries and hundreds of towns and cities of the global South, with affiliates actively sharing knowledge and experience on strategies for engagement of the state.

Savings groups provide the structure for individual involvement in the activity of SDI affiliate organisations, with groups providing basic financial services of deposit accounts and loans unavailable commercially to people with unstable income or lacking identity documents (Shand 2017). Savings groups are formed among neighbours, with each group having a membership of around 40 people; the small scale 
allowing all members to be involved in the management of funds to ensure effective peer accountability. In keeping with the low and irregular incomes of members, deposits into savings are made on a daily basis and may amount to just a few cents. Collections are made door-to-door with deposits checked and recorded in a savings book and reported by the group treasurer at weekly meetings (see D'Cruz and Mudimu 2013 discussion of community savings in Uganda). Savings groups may offer a number of separate accounts, as decided by members, including a collective loan fund used to create financial asset for land and housing investment and accounts intended to cover emergencies of individual members, such as for healthcare and burial costs.

The practice of daily deposits of money is a 'ritual' of interaction between members, with regular contact providing the 'social glue that binds communities' together (Robins 2008: 90). McFarlane (2012: 2810) discusses SDI affiliate savings schemes in India as representing 'an ethic of collective commitment to social development'. Beyond the practical benefits of community owned savings and loans, Mitlin et al. (2011) highlights how savings groups are important for efficacy, with women developing leadership skills, outside of the home, that challenge the limits of gendered roles within communities. 'The collective nature of savings helps to ensure that women are nurtured as they develop a new understanding of themselves and their capabilities' (Satterthwaite and Mitlin 2014: 162). Savings groups provide the foundational blocks of much larger structures at settlement, city and national levels that create collective identity, a sense of belonging and the capacity to act (Millstein et al. 2003; D’Cruz 2014).

Regular contact among peers, the creation of small financial assets and involvement in group activity, where individuals are respected and supported, creates a positive environment to build self-confidence, mutual reliance and centrally, a sense of efficacy (D’Cruz and Mudimu 2013). These micro-structures of engagement, problem solving and discussion enable, what Sampson (2014: 129) describes, in a US context, as interactions vital to shape expectation and "generate shared norms outside of the 'strong tie' setting of friends and kin." The communality and bonds of mutual reliance provides a counterpoint to the isolating power of poverty, with efficacy formed through association and experience of collective action. While there are significant challenges to bringing heterogeneous populations together, recognising how embedded cultural differences (Woolcock and Narayan 2006; Krishna 2009), instability (Sampson et al. 1997) and weak social capital (Hulme and Mosley 1996; Thorp et al. 2005) create barriers to collective working, regular localised activity builds trust and the functional capability of groups to contribute to development.

\section{Operationalising Social Commitment}

The creation of social and practical structures that bind people together enables communities to engage in development activity that goes beyond an individual ability to affect economic, environmental and institutional conditions. However, while networks offer the potential for community endeavour, they have to be activated and sustained and overcome collective action problems (Olsen 1965). For SDI affiliates, countering 'rational self-interest' to build individual commitment to collective action is at the heart of mobilisation: balancing individual and communal benefits in ways that are empowering, build trust and contribute to the efficacy of group activity (Patel and 
Bartlett 2009). In keeping with discussions in the social movement literature, shared cause and objectives can overcome barriers of social difference, where collective action is focused on addressing common problems (Benford and Snow 2000; Tilly and Tarrow 2007). The practices of SDI enable individuals gain practical benefits from the formation of savings schemes, the availability of group support and the potential to obtain improved housing. These benefits, scaled at settlement and city level, create substantial capacity to deliver collective action through organised contributions to projects of development.

Forms of inclusive development are evident across SDI affiliate activity in the creation of Urban Poor Funds in more than 16 countries that provide finance to secure land title and deliver housing construction (Mitlin 2008; Satterthwaite et al. 2011), collaborations with city and national governments to map and upgrade informal settlements (Appadurai 2012; Banana et al. 2015) and the adaption of regulations governing land use and building standards (Mitlin and Muller 2004). Creating community assets and infrastructure is possible because people feel they have efficacy, through collective working, and are able to deliver new facilities or engage authority on development issues. For example, National Slum Dwellers Federation of Uganda obtained land from Jinja Municipal Council to construct sanitation units at Rubaga Market to radically improve access to toilet and washing facilities for residents of low income communities. Construction work was funded and undertaken by Federation members, under the supervision of a local authority engineer. Collective action brought significant benefit for the $82.5 \%$ of slum residents in Jinja who lacked access to toilets within their compound, while also demonstrating to the Municipal Council the capacity of collective community working (Nyamweru and Dobson 2014). Also the Mumbaibased group Mahila Milan (Women Together) organised to represent the needs of pavement dwellers with city authorities. Savings were used as a tool to engage and mobilise members, with the groups encouraged to reflect on the issues most important to the poorest communities and identify potential solutions. Discussion and planning provided a practical means of operationalising the growing sense of efficacy among members and led to city-wide documentation and mapping of informal settlements, a community toilet programme and the setting up of community-police partnerships across slum areas of Mumbai (Mitlin et al. 2011).

The starting point for all of these interventions was the mobilisation of individuals, which entailed sharing information, building confidence, taking and giving responsibility and, of greatest importance, enabling people to feel some control over their lives and environments. Preparing people to be 'included' 'is not about bricks, land and services alone [... it] is about realizing real democratic, developmental citizenship' (Bolnick and Bradlow 2010: 41). Overcoming collective action problems and building efficacy is achieved where people are linked, jointly accountable and have a reserve of trust that shapes behaviour and expectations for the future (Ostrom and Ahn 2007).

Translating supportive social relationships into a resource for inclusive development action is achieved through group structures, maintaining the bonds of reciprocal support, which 'glue' participation into collective action. The modality of the SDI approach emphasises grassroots leadership and decision making, with technical support from NGO partners. The inclusive approach discourages free-riding as individual members are subject to peer accountability and have a strong desire to 
maintain good relations with the group. The success of the SDI approach is consistent with the research of Thorp et al. (2005), who found that shared decision making and strong individual identification within group settings creates an incentive for cooperation that weakens tendencies towards self-interested behaviours. The emphasis on 'bottom-up' leadership ensures commitment of members to the task, but also reverses established ideas of power relations in development, by validating the contribution of collective actors.

\section{Methodology}

Research data for this paper draws from fieldwork undertaken in Zimbabwe during 2013 and 2014, with members of the Zimbabwe Homeless Peoples Federation (hereafter ZHPF), its partner Dialogue on Shelter Trust (Dialogue) and the City of Harare Council. The research investigated the impact of collaborative housing and basic service infrastructure projects, delivered jointly by ZHPF, Dialogue and the City of Harare Council, on the application of formal rules governing land use and on attitudes to organised poor communities as development agents. The fieldwork also traced changes in the thinking and behaviour of ZHPF members, resident in two lowincome communities in Harare involved in upgrading activity, to identify shifts in efficacy. Data was collected and triangulated through semi-structured interviews and focus groups with 18 community members, four leaders of ZHPF, 11 city government officials, three senior NGO managers from Dialogue and four stakeholder organisations working at a national level in Zimbabwe. Interview data was supplemented by analysis of policy documents and management information obtained from ZHPF, Dialogue and the City of Harare Council and press reports on issues of housing need in the City.

Participants were engaged in the research on the basis of their experience of collaborative working between communities (ZHPF and Dialogue) and the state (City of Harare Council) in Harare. Selection focused on informants ability to reflect on historical changes in behaviour and attitudes over a 16-year period and comment on the activity of ZHPF and Dialogue to establish structures of mutual support among community members. Individual respondents were also asked to comment on how their own feelings of efficacy changed over the period and what contributed to these changes. Collecting testimony from multiple perspectives on the shared experience of collaboration was used to analyse changing patterns of behaviour among community and state agents. Interview and focus group data were transcribed and coded for analysis and, along with documentary evidence, used to identify discursive and operational shifts in the application of formal institutions and how communities responded to and challenged rules governing land and housing provision.

\section{Efficacy in Context}

Zimbabwe has a turbulent history since independence in 1980. Formed initially with strong developmentalist principles, the country's post-colonial ambitions have largely been thwarted by a long series of political and economic crises that have led to failing livelihoods and an exclusionary mode of political rule (Bracking 2005; Potts 2010). 
State bureaucracy has been politicised as the governing party, ZANU-PF, sought to contain political opposition through the use of violence and manipulation of public administration (Sachikonye 2006). The adverse conditions in Zimbabwe have made the direct challenge of Government authority through institutional routes very dangerous, forcing more creative approaches to addressing gaps in public service delivery and engaging the state at city and national levels (Moyo et al. 2000).

These conditions have had a negative impact on political participation, as the routes of negotiation with government narrowed. Through the 1990s, regulations were introduced that gave Zimbabwean government and its security forces wide ranging powers to quash any political and civic activity that could be construed as counter-nationalist (Alexander 1998; Bratton and Masunungure 2011). These policies contributed to, as Sachikonye (2011) describes, a culture of fear, which in turn undermined citizen trust in the systems and structures of the state. The clearest demonstration of the fractured relationship between people and the state was Operation Murambatsvina (Operation Restore Order) in 2005, a militarized assault on the urban poor to 'clear' illegal structures and informal settlements. Operation Murambatsvina was undertaken as a shock tactic, with some 700,000 people losing their homes or businesses over a 3month period (Tibaijuka 2005). Potts (2011) suggests that one in seven urban residents was made homeless by the 'tsunami' of demolitions that targeted any structure without planning consent. For low income urban populations it underlined the disconnection between citizens and the state and reinforced the need to drive the upgrading of settlements through collective action from within communities.

As the violent nature of political rule in Zimbabwe closed off options to directly challenge the state, communities sought alternative routes to address serious issues of urban poverty. ZHPF and Dialogue were established in 1997, with practical assistance from SDI affiliate organisations in South Africa and Namibia, to build networks of mutual support among residents of low income settlements and holding camps in Harare. ${ }^{1}$ In keeping with the SDI model, initial engagement activity was constructed around the formation of women-led savings groups. These groups in Harare met a practical need for basic financial services, while also providing a reason for people to come together, articulate shared problems and make plans for the future.

A core goal for ZHPF and Dialogue was to encourage neighbourhood responses to housing and service need through collective action, with community activity used as a vehicle to drive inclusive forms of development from the grassroots. Given the aggressive character of Zimbabwean government, it was important for ZHPF and Dialogue to build capacity and efficacy within low income communities, as a core practice of participation, in order to engage the state in discussions about development challenges. In the absence of 'invited spaces' of negotiation with city and national government, ZHPF and Dialogue 'invented spaces' (borrowing from Miraftab 2004) for engagement of state agencies at different levels. These included community activities and events where city officials and politicians were invited take part and NGO

\footnotetext{
${ }^{1}$ Holding camps are 'temporary' settlements established on the outskirts of cities by the Zimbabwean government as locations for people displaced by large scale demolitions of illegal dwellings. Holding camps, according to Kamete (2007) and Potts (2010), were used to assess and process people: those without resource or employment in the city were directed to return, often forcibly, to rural areas. These camps had infamous reputations, such as Caledonia Farm, of being 'places of extreme deprivation and terrible environmental conditions' (Potts 2010: 228).
} 
organised meetings with authorities that community members would also attend. The invention of spaces of engagement was intended to make government officials aware of the issues of urban poverty, to build the capability of organised communities to engage in negotiation and with the state and practice citizenship (Miraftab and Wills 2005), drawing from the knowledge and growing sense of efficacy gained through acting as development agents.

\section{Efficacy in Action}

The remainder of this paper discusses efficacy and building collective action to address the challenges of poverty and urban life in Zimbabwe. Drawing from data collected in Harare, the following section discusses how efficacy is created and employed to support inclusive development. Data is used to highlight how members of the poorest communities are able to have active involvement in development and how this has affected relationships with the City Council in Harare to create opportunities for collaborative action.

\section{Building Social Bonds}

Overcoming a fear of retribution and building a belief in the strength of collective voice were essential to enabling discussion between communities and government in Harare. Individual experience of violence and the operation of institutional controls over access to public services, provided a major barrier to residents in low-income communities engaging city authorities on issues of housing and services. The politicised character of public administration and violent enforcement of planning regulations undermined the efficacy of poor urban populations and meant that direct action was unacceptably high risk. A ZHPF leader commented:

[...] it is common knowledge in Zimbabwe that if you try to use muscles, the people in Zimbabwe are good at using muscles, especially the state [...] so if we had taken the approach of using muscles we would have been on the losing side [...] some of our members are going to die, and that has happened before. (Workshop discussion, April 2014).

In this context, mobilising individuals, through the creation of community networks, provided the means to build confidence for collective action, as a precursor to engagement of city government. Women-led savings groups provided a vehicle to identify and build local support and raise the confidence of members that collectively they could improve housing and environmental conditions. Establishing the social infrastructure to address individual feelings of isolation and sense of powerlessness is at the core of ZHPF activity to build efficacy. For members, to be mobilised into the group is 'being taught or retaught something that you have forgotten'; connecting with a sense of self and community that has been lost under the pressure of poverty (ZHPF interview, July 2013). The approach resonates with Freirean 'conscientization', as the mechanics of the poor coming together, in 'the process by which human beings participate critically in a transforming act' (Freire 1985: 106). For ZHPF members, the 
transformation is from an individual condition of coping to one of social membership where collective action is possible.

The creation of savings groups provides the foundation for community engagement in Harare. ZHPF savings groups have between 30 and 50 members, a majority of whom (some two thirds in Harare) are women. Membership of ZHPF savings groups is open to all residents of low-income communities, with the requirement that members commit to regular saving and to being involved in communal activity. In practice, the condition of active participation is a barrier for some of the urban poor, who may be willing to save money but unwilling to engage in community activity. Savings groups have a dual purpose: to provide a structure for micro-savings and loans among members and to facilitate the creation of social bonds. This latter function is particularly important for creating efficacy, as regular meetings provide an opportunity for individuals to air the 'everyday talkings of poverty' (ZHPF interview, July 2013). Through deconstructing problems and envisaging solutions that draw upon the collective resources and capabilities available within ZHPF, individuals become more confident and able to manage their experiences of poverty. As with the findings of Sampson et al. (1997) the clear rules, bonds of mutual trust and focus on goals of common importance provide a strong positive incentive that reinforces belief in collective action.

Weekly meetings of the savings groups provide an opportunity to catch up with the activity of friends, to seek advice and support from the group and to engage in joint planning and decision making. In line with the SDI model, decisions on loans and community projects are taken at the grassroots level to build ownership and commitment to the federated approach and to reinforce bonds of mutual support. A female member of ZHPF commented that she felt happy if she 'is able to help somebody or somebody can learn from what I do and I can learn from them' (interview, July 2013). Another member valued the practical support provided to her family by the group when she was hospitalised. The impact of being part of ZHPF was summarised by a female member who said that the group meetings helped her to 'feel that I am somebody among others, it uplifts me and gives me confidence in life' (interview, July 2013). Feedback from ZHPF members in Harare on the significance of savings groups indicate that belonging builds their feelings of efficacy, as illustrated through the following quotations.

As a member of my [savings] group I know that I will be helped whenever there is a problem and the whole group will come together. The group gives me more confidence and power to move on and tackle the challenges in my life. (Interview, July 2013).

Being a member of the Federation has been fantastic! I have achieved something that I was not going to achieve when I was alone. But when I joined the Federation I achieved a stand - land in the Capital City! (Interview, July 2013).

For the collective, mobilisation through savings groups creates capacity to tackle development problems at a neighbourhood level and to scale up action by building a network of participants active within the city. Working to release the latent potential of individuals, coming together within organised groups, helps to realise the core strategy of ZHPF to engage rather than confront government authorities on issues 
of access to housing and basic services. The approach taken by ZHPF and Dialogue is to present communities as capable agents of change by 'demonstrating what is possible $[\ldots]$ rather than saying that this doesn't work, actually presenting what works' (interview with Dialogue, February 2013). Actively engaging in discussion and problem solving reinforces belief in the efficacy of the group, which in turn substantiates collective action.

\section{Relations with the State}

For inclusive approaches to development to be effective, it is insufficient that communities organise and are open to collaborative working with the state. State actors must also challenge institutional, practical and attitudinal barriers in order to view people in poverty as prospective partners in development (Appadurai 2001). As suggested by Cleaver (2007) and Bandura (2000) above, efficacy relies on the feasibility of actions within prevailing contexts. Evidence from the City of Harare illustrates how squatters and residents of informal settlements have been historically viewed just as a problem of urban management.

In the past if someone who is powerful, financially and economically like that, says that there are informal settlers next door to me and they are a nuisance to me, we would come in with bulldozers and pull everything down and put those people in tippers and send them back to their rural areas (interview City of Harare, February 2013).

These attitudes are formalised in regulation, policy and practices to create a framework for governing relations between state organisations and low-income communities. As such these institutions provide a significant barrier to implementing inclusive approaches to development because they reinforce opposition, where communities are the object of management rather than potential collaborators. In Harare, ZHPF and Dialogue made strenuous efforts over a 16-year period to build and maintain spaces for discussion with city government. For ZHPF, this formed part of core strategy to demonstrate the efficacy of communities and 'prove to government that we are the people that are not homeless and hopeless but homeless and hopeful' (interview with ZHPF, May 2013). From the perspective of Harare City Council, the repeated assertion by communities to be involved in improving the conditions of informal settlements was initially an irritant: 'first we were not even prepared to discuss with them [ZHPF and Dialogue]. But when they kept pestering us we began opening up' (interview with City of Harare Council, May 2013). ZHPF by asking for meetings, presenting ideas and inviting city officials to participate in community-based events gradually overcame negative attitudes and the embedded administrative practices that prevented collaboration between the City Council and communities.

The strategy of engagement adopted in Harare enabled ZHPF to increase their understanding of how the city government worked in ways that allowed them to refine their approaches and target particular decision makers and processes. Awareness of the political and administrative systems of the City Council was a keystone for building efficacy, as knowledge demystifies the operation of power to make actions seem more realistic. It also reinforces the willingness of individuals to support collective activity 
where there is a chance that they can address long standing problems, as suggested by Bandura (2000). Knowledge contributes to efficacy by reducing feelings of risk that deter practical engagement in problem solving, thereby addressing the information deficit that underpin feelings of uncertainty (Thorp et al. 2005).

To illustrate this, a key challenge for low income communities in Harare, identified by ZHPF, was the inconsistent provision of basic services such as waste collection, reticulated water supply and sewage. Households in low income settlements were being charged for these services, but the City Council was not ensuring regular provision. Households who refused to pay rates, for lack of service delivery, were generating large debts, but were unable to engage authorities to raise concerns. ZHPF groups made representations to the City Council to improve services and reschedule debt, based on their knowledge of 'the responsibilities of the City and the responsibilities of the community’ (Interview ZHPF, May 2013). Accumulated knowledge underpinned the confidence of community members that they had a voice and could hold the City Council to account. While the representations had limited immediate effect on the practices of the City Council in the provision of services, it opened a channel for dialogue allowing ZHPF members to engage in negotiating a solution to problems that were previously unavailable: 'in other communities where they do not have this knowledge, they just shiver' (Interview ZHPF, May 2013).

Building efficacy extended beyond discussion to action, addressing key challenges for low income communities. ZHPF members reported how the weak public finances, combative national politics and lack of delivery capacity undermined the Council's ability to meet public service commitments to maintaining and extending existing urban basic service provision. The intractability of this situation was an incentive for the City Council to look beyond the limits of existing practice, to establish more experimental and inclusive approaches to development, albeit on a small scale, working through ZHPF. A City of Harare official commented on the signing of a MOU with ZHPF and Dialogue to upgrade a low income settlement, '[w]e have obligations, they have obligations and together this is our project' (interview February 2013). Through the MOU the City Council approved an exception to urban planning regulations, allowing ZHPF to begin formalising a peripheral settlement, without first installing reticulated water and sanitation systems as required by law. ZHPF and Dialogue negotiated the use of boreholes and dry sanitation units as temporary measures, pending infrastructure being in place. The decision allowed incremental housing construction to proceed on site, but also demonstrated the capacity of collective action to deliver urban development.

\section{Maintaining Efficacy}

Sampson et al. (1997) argue that efficacy is situated rather than global and formed in relation to specific tasks and intended effects. The implication being that efficacy is created and renewed through action and the outcome of actions. For members of ZHPF in Harare, the creation of social networks and savings groups is located in the specific contexts of coping to meet the everyday challenges of poverty. The initial reasons for joining ZHPF, expressed by members, are largely practical and focus on improving access to land, housing and healthcare through group structures. However, ZHPF members highlight a wider benefit of reduced isolation and building confidence in all 
aspects of life. A male interviewee reflected on membership of ZHPF: '[i]n the end I understood that it was not just about these stands [serviced housing plots], it was about the whole affair and that was the interesting part for me' (ZHPF interview July 2013). A female interviewee commented that 'the Federation [ZHPF] is a family and you won't need to deal with problems on your own' (ZHPF interview, July 2013). Efficacy is created both through working towards the achievement of specific tasks, such as obtaining a housing 'stand' but has deeper impact, and is maintained, through small acts of reciprocity to deal with recurring problems of life.

ZHPF, in common with other social movement organisations (Tilly and Tarrow 2007), have to maintain momentum of engagement to preserve the coherence of the group. They support small scale environmental projects, skills sharing among members (such as candle making, sewing and construction skills) and enterprise initiatives (i.e. informal markets) as a means of maintaining dynamism and preventing loss of membership. In addition to the regular meetings of savings groups, these activities provide a means of invigorating and mobilising members to sustain their contributions to the group, while also providing practical benefits that help improve livelihoods. Maintaining active involvement in the civic life of ZHPF reinforces a sense of purpose and belonging that helps to counteract free-riding, with close interpersonal relationships providing the basis for member accountability and actions.

Operation Murambatsvina was a fundamental challenge to ZHPF in 2005. The ferocity and speed of the state-led demolitions of informal structures had a direct impact on many members, who lost homes and businesses. More broadly, Operation Murambatsvina was a breach of trust, undermining the nascent relationship between ZHPF, Dialogue and city and national government. It clearly demonstrated the power of government and the mutable nature of politics, providing a salutary lesson to ZHPF leaders, as the following comment suggests.

So that was quite a huge dent but to an extent it also helped to strengthen the movement because we became aware that the environment can change any time any minute we should not just sit and relax we should anticipate some changes made by government or whoever. So we have to be very strong so sometimes we plan for evictions that are not coming because we never know whether it is going to come or it may not come. So it kind of strengthened (interview ZHPF leader, 8 May 2013).

The demolitions caused some members to leave the city, but for others, it provided a demonstration of the importance of the group and their ability to provide practical support during crisis. A ZHPF member commented 'if not for the Federation (ZHPF) I think [...] I would have decided to go back home to the rural area' (interview July, 2013). For those that remained in the cities after Operation Murambatsvina, the trauma appears to have reaffirmed their belief in efficacy of the group and its importance as a way to deal with the unpredictability of state politics. Operation Murambatsvina did however have implications for relations between communities and Harare City Council officials. ZHPF expressed greater caution in their relationships with city government after Operation Murambatsvina, as illustrated in the quotation above, but worked to maintaining an open dialogue to not lose years of patient engagement with the City Council. The efforts to rebuild trust were perhaps made easier because Operation 
Murambatsvina was viewed as an attack by national government on cities as sources of opposition to ZANU-PF rule (Hammar 2008). City officials also recognise the ineffectiveness of large scale demolition after Operation Murambatsvina: 'the solution is not really moving people. The solution lies with the people themselves; engaging with them. So we have not done really enforcements since then [2005] and we are not thinking of doing enforcements. We are thinking along the lines of dialogue with the people yes, talking to them seeing how best we can solve it' (Interview City Council 7 May 2013). For ZHPF recovery from Operation Murambatsvina has deepened bonds of trust among members and reaffirmed objectives to influence state responses to development challenges through collective action.

\section{Discussion and Conclusions}

The approach taken in Zimbabwe has been developed in a particular institutional context, where there are few routes to engage in political debate and government, at national and city levels, lacks the financial and human capacity to drive sustainable development. While the case study of Zimbabwe is set within a specific political environment, the pattern of government relations with residents of urban informal and low income settlements found across global South is often similarly characterised more by confrontation than inclusion. The experience of SDI federations, operating in 32 countries, demonstrates the necessity of both building the efficacy and capacity of communities to engage in development, while also creating opportunities for negotiation and collaboration with government, at different levels, to deliver improvements in housing, infrastructure and public services to the urban poor. While ideas of inclusive development are strongly articulated in international policy, the mechanisms of realising inclusion are less well developed.

Focusing on efficacy, as a core characteristic of inclusive development, offers a perspective on important debates about how development policy is operationalised. The SDG urban target (goal 11) and more recently the Habitat III New Urban Agenda discuss inclusive development as process of participation that leads to the civic engagement of urban residents and fosters sense of belonging and social cohesion, as core characteristics of human settlements. Inclusion is also used to describe distribution of benefits where all city inhabitants are able to have decent and dignified lives and realise their full human potential. Efficacy provides a linking element for these targets, achieved through the willingness and commitment of communities to contribute time, energy and resources to realising urban development goals.

Merely expanding the number of 'invited spaces' of participation without first addressing existing 'entrenched relations of dependency, fear and disprivilege' (Cornwall 2004: 2) is unlikely to create the quality of deliberation, input and ownership that inclusion promises. Similarly, assuming that inclusion can be programmed and delivered through donor contracted channels seems equally unlikely to achieve the depth of impact sought. Lessons from SDI, and specifically from Zimbabwe, highlight the iterative nature of building confidence and trust that can lead to increased sense of efficacy. Where this process is based in and led by communities and there are regular opportunities to test the limits of reciprocal support, people adapt and are willing to take risk and invest in collective action. Gaventa and Barrett (2010) indicate even in least 
democratic and stable political environments (including Zimbabwe) community-based associations can play a vital role in constructing citizenship, improving practices of participation, strengthening accountability and contributing to social cohesion. As Peter Evans (2004) finds in his study Kerala India, even where processes are messy, people will invest time and energy into collective actions where they can shape real outcomes.

There are, however, inherent limits to community driven approaches to inclusion that have implications for development policy and practice. First, states have an important enabling role to create conditions for inclusive development: to be actively receptive to community leadership and to adapt institutionalised responses that may exclude poor communities from involvement in development decision making. As illustrated by Ostrom (1996) and Thorp et al. (2005), state hostility can prevent successful group formation and undermine the roots of emergent efficacy and collective action. With increasing policy emphasis on inclusive development, supporting and sustaining the efficacy of communities should perhaps be repositioned as a primary goal of development programming. The essential contribution of capable and active communities to provide input and leadership into complex projects of urban development warrants a deeper understanding of how efficacy is created and sustained if global development targets are to be met.

Second, limits are also present in the operation of grassroots organisations as development agents. As in the example of ZHPF in Zimbabwe, while membership was open to all residents of low income settlements, this did not mean that all were included. The SDI methodology requires a firm commitment from its members to saving and participation that is not attractive to all and in practice excludes some people. A consequence of collective approaches, particularly where members are bound by social ties of reciprocity, is a limit to scale. This challenge is addressed in the SDI model by the federating of small savings groups at city and national levels, but this inbuilt constraint means that collective inputs are most effective where they are made as discrete contributions to targeted activity, with a more difficult translation to larger spatial scales.

Organised communities have capacity to be creative and to invent new spaces for engagement and dialogue with the state. In the context of Zimbabwe, the formation of these spaces has to be effective in establishing new relationships, but avoid confrontation or politicisation of activity that make the group vulnerable to state action. By building efficacy, organised communities are able to expand the practices of participation, as described by Gaventa and Barrett (2010), to deepen knowledge about how power is exercised and to formulate collection action. In contrast to more open political contexts, the forms of dissent and grassroots action, such as observed by Robins (2014) in South Africa, that successfully combine direct action with the 'slow activism' of constructive engagement with the state, are not viable in Zimbabwe. The violent nature of politics means that the creation of efficacy provides a form of disruption in the rejection of the passive status of the urban poor. By demonstrating capability to organise, to problem solve and to act collectively is a form of resistance to systems of control and subordination. The response to Operation Murambatsvina demonstrated the resilience inherent in efficacy to sustaining the efforts of ZHPF members to remain in Harare and committed to collective action.

In conclusion, this paper has argued that building efficacy is an essential ingredient to the achievement of inclusive development. The expectation that people living in 
poverty can easily overcome marginalisation and a myriad of economic and social challenges to meaningfully participate in development is flawed. Evidence from the global activity of SDI and the specific experience of the Zimbabwe demonstrates active and engaged communities contributing to urban development is both possible and impactful, but relies on creating architecture of mutual support among the poorest urban residents. Centrally, inclusive development relies on creating a culture of trust, both within low income settlements to enable people to move beyond the familiar environments of coping, and between state agencies and organised communities. Building efficacy provides the foundation to release the latent resources, human capacity and knowledge of the poor to deliver the goals set out in the SDGs. However, full potential can only be achieved where the structures and institutions of development create the conditions to realise the benefits of mobilised communities.

Acknowledgements I would like to thank Diana Mitlin and Sam Hickey and the two anonymous reviewers for their helpful comments on this paper.

Funding information Data in this paper is taken from doctoral research undertaken between 2011 and 2014, supported by an Economic and Social Research Council CASE studentship [ES/J500094/1] with the International Institute for Environment and Development.

Open Access This article is distributed under the terms of the Creative Commons Attribution 4.0 International License (http://creativecommons.org/licenses/by/4.0/), which permits unrestricted use, distribution, and reproduction in any medium, provided you give appropriate credit to the original author(s) and the source, provide a link to the Creative Commons license, and indicate if changes were made.

\section{References}

Alexander, J. (1998). Dissident perspectives on Zimbabwe's post-independence war. Africa, 68(2), 151-182.

Ali, I., \& Son, H. N. (2007). Defining and measuring inclusive growth: application to the Philippines. ERD working paper 98. Manila: Asian Development Bank.

Aliber, M. (2001). Study of the incidence and nature of chronic poverty and development policy in South Africa: an overview. Chronic poverty research centre working paper 3. Manchester: IDPM University of Manchester.

Appadurai, A. (2001). Deep democracy: urban governmentality and the horizon of politics. Environment and Urbanization, 13(2), 23-45.

Appadurai, A. (2004). The capacity to aspire: culture and the terms of recognition. In V. Rao \& M. Walton (Eds.), Culture and public action (pp. 59-84). Stanford: Stanford University Press.

Appadurai, A. (2012). Why enumeration counts. Environment and Urbanization, 24(2), 639-641.

Banana, E., Chitekwe-Biti, B., \& Walnycki, A. (2015). Co-producing inclusive city-wide sanitation strategies: lessons from Chinhoyi, Zimbabwe. Environment and Urbanization, 27(1), 1-20.

Bandura, A. (2000). Exercise of human agency through collective efficacy. Current Directions in Psychological Science, 9(3), 75-78.

Bandura, A. (2001). Social cognitive theory: an agentic perspective. Annual Review of Psychology, 52, 1-26.

Benford, R. D., \& Snow, D. A. (2000). Framing processes and social movements: an overview and assessment. Annual Review of Sociology, 26, 611-639.

Bolnick, J., \& Bradlow, B. (2010). Rather a better shack now than wait twenty years for a formal house. Trial, 104(1), 35-41.

Bracking, S. (2005). Development denied: autocratic militarism in post-election Zimbabwe. Review of African Political Economy, 32(104-105), 341-357.

Bratton, M. Masunungure, E. (2011) 'The anatomy of political predation: leaders, elites and coalitions in Zimbabwe, 1980-2010'. Developmental leadership program, research paper 9. University of Birmingham. 
Cleaver, F. (2007). Understanding agency in collective action. Journal of Human Development and Capabilities, 8(2), 223-244.

Cornwall, A. (2004). Introduction: new democratic spaces? The politics and dynamics of institutionalised participation. IDS Bulletin, 35(2), 1-10.

D'Cruz, C. (2014). Community savings: a basic building block in the work of urban poor federations. IIED working paper. London: International Institute for Environment and Development.

D’Cruz, C., \& Mudimu, P. (2013). Community savings that mobilize federations, build women's leadership and support slum upgrading. Environment and Urbanization, 25(1), 31-45.

Du Toit, A. (2004). Social exclusion' discourse and chronic poverty: a South African case study. Development and Change, 35(5), 987-1010.

Evans, P. (2004). Development as institutional change: the pitfalls of monocropping and the potentials of deliberation. Studies in Comparative International Development, 38(4), 30-52.

Freire, P. (1985). The politics of education: culture, power and liberation. Basingstoke: Macmillan.

Gaventa, J., \& Barrett, G. (2010). 'So what difference does it make? Mapping the outcomes of citizen engagement' IDS working paper 347. Brighton: Institute of Development Studies. University of Sussex.

Gupta, J., Baud, I., Bekkers, R., Bernstein, S., Boas, I., Cornelissen, V., Iguchi, M., Kanie, N., Kim, R. E., Bastos Lima, M. B., Obani, P., Schoof, P., Stevens, C., \& van Zoomeren, D. (2014). Sustainable development goals and inclusive development. POST2015/UNU-IAS policy brief 5. Tokyo: United Nations University Institute for the Advanced Study of Sustainability.

Hammar, A. (2008). In the name of sovereignty: displacement and state making in post-independence Zimbabwe. Journal of Contemporary African Studies, 26(4), 417-434.

Hickey, S. (2013). 'Thinking about the politics of inclusive development: towards a relational approach'. ESID working paper 1. Effective states and inclusive development research Centre. Manchester: University of Manchester.

Hickey, S., \& Du Toit, A. (2007). Adverse incorporation, social exclusion and chronic poverty. Chronic poverty research centre working paper 81 . Manchester: IDPM University of Manchester.

Hulme, D., \& Mosley, P. (1996). Finance against poverty. London: Routledge.

Hulme, D., \& Shepherd, A. (2003). Conceptualising chronic poverty. World Development, 31(2), $403-423$.

Kamete, A. Y. (2007). Cold-hearted, negligent and spineless? Planning, planners and the ejection of "filth" in urban Zimbabwe. International Planning Studies, 12(2), 153-171.

Krishna, A. (2009). Why don't 'the poor' make common cause? The importance of subgroups. The Journal of Development Studies, 45(6), 947-965.

McFarlane, C. (2012). The entrepreneuial slum: civil society, mobility and the co-production of urban development. Urban Studies, 49(13), 2795-2816.

MacKinnon, D. (2010). Reconstructing scale: towards a new scalar politics. Progress in Human Geography, 35(1), 21-36.

Millstein, M., Oldfield, S., \& Stokke, K. (2003). uTshani BuyaKhuluma - the grass speaks. The political space and capacity of the South African Homeless People's Federation. Geoforum, 34(4), 457-468.

Mitlin, D. (2008). With and beyond the state - co-production as a route to political influence, power, transformation for grassroots organisations. Environment and Urbanization, 20(2), 339-360.

Mitlin, D. (2014). Politics, informality and clientelism-exploring a pro-poor urban politics'. Effective states and inclusive development working paper 34. Manchester: University of Manchester.

Mitlin, D., \& Muller, A. (2004). Windhoek, Namibia: towards progressive urban land policies in Southern Africa. International Development Planning Review, 26(2), 167-186.

Mitlin, D., Satterthwaite, D., \& Bartlett, S. (2011). Capital, capacities and collaboration: the multiple roles of community savings in addressing urban poverty. IIED human settlements working paper-poverty reduction in urban areas, 34. London: International Institute for Environment and Development.

Miraftab, F. (2004). Invented and invited spaces of participation: neoliberal citizenship and feminists' expanded notion of politics. Wagadu: Journal of Transnational Women's and Gender Studies. http://webhost1.cortland.edu/wp-content/uploads/2014/02/miraftab.pdf.

Miraftab, F., \& Wills, S. (2005). Insurgency and spaces of active citizenship: the story of Western Cape antieviction campaign in South Africa. Journal of Planning Education and Research, 25, 200-217.

Moyo, S., Makumbe, J., \& Raftopoulos, B. (2000). NGOs, the state and politics in Zimbabwe. Harare: Sapes Books.

North, D., Wallis, J. J., Webb, S. B., \& Weingast, B. R. (2013). In the shadow of violence. Cambridge: Cambridge University Press.

Nyamweru, H., \& Dobson, S. (2014). 'Building partnerships between urban poor communities and local governments'. IIED working paper. London: International Institute for Environment and Development. 
Olsen, M. (1965). The logic of collective action: public goods and the theory of groups. Cambridge Mass: Harvard University Press.

Ostrom, E. (1996). Crossing the great divide: co-production, synergy and development. World Development, 24(6), 1073-1087.

Ostrom, E., \& Ahn, T. K. (2007). 'The meaning of social capital and its link to collective action'. Workshop in political theory and policy analysis working paper 07-19. Bloomington: Indiana University.

Parnell, S. (2016). Defining a global urban development agenda. World Development, 78, 529-540.

Patel, S., \& Bartlett, S. (2009). Reflections on innovation, assessment and social change: a SPARC case study. Development in Practice, 19(1), 3-15.

Patel, S., \& Mitlin, D. (2004). Grassroots-driven development: the alliance of SPARC, the National Slum Dwellers Federation and Mahila Milan. In D. Mitlin \& D. Satterthwaite (Eds.), Empowering squatter citizen; local government, civil society and urban poverty reduction (pp. 216-241). London: Earthscan Publications.

Pieterse, E. (2008). City futures: confronting the crisis of urban development. London: Zed Books.

Potts, D. (2010). Circular migration in Zimbabwe and contemporary Sub-Saharan Africa. Suffolk: James Currey.

Potts, D. (2011). Shanties, slums, breeze blocks and bricks. City, 15(6), 709-721.

Prowse, M. (2003). Towards a clearer understanding of 'vulnerability' in relation to chronic poverty. Chronic poverty research centre working paper no 24 IDPM. Manchester: University of Manchester.

Rauniyar, G., \& Kanbur, R. (2010). 'Inclusive development: two papers on conceptualization, application and the ADB perspective'. Cornell University Working Paper 2010-01. New York: Cornell University.

Robins, S. (2008). From revolution to rights in South Africa: social movements, NGOs and popular politics after apartheid. Suffolk: James Currey.

Robins, S. (2014). Slow activism in fast times: reflections on the politics of media spectacles after apartheid. Journal of Southern African Studies, 40(1), 91-110.

Sachikonye, L.M. (2006). 'The impact of operation Murambatsvina/clean up on the working people of Zimbabwe' report prepared for the Labour and Economic Development Research Institute of Zimbabwe (LEDRIZ). [Online] Available: http://archive.niza.nl/docs/200608281522024680.pdf [Downloaded 7 March 2013].

Sachikonye, L. (2011). When a state turns on its citizens: 60 years of institutionalised violence in Zimbabwe. Johannesburg: Jacana Press.

Sampson, R. J. (2014). Collective efficacy theory: lessons learned and directions for future inquiry. In T. L. Anderson (Ed.), Understanding deviance: connecting contemporary and classical perspectives (pp. 128139). London: Taylor and Francis.

Sampson, R. J., Raudenbush, S. W., \& Earls, F. (1997). Neighborhoods and violent crime: a multilevel study of collective efficacy. Science, 277(5328), 918-924.

Satterthwaite, D., Mitlin, D., \& Patel, S. (2011). Engaging with the urban poor and their organizations for poverty reduction and urban governance. an issue paper for UNDP. New York: UNDP.

Satterthwaite, D., \& Mitlin, D. (2014). Reducing urban poverty in the global South. London: Routledge.

Sen, A. (1999). Development as freedom. Oxford: Oxford University Press.

Shand, W. (2017). Local-level finance: improving the accountability and effectiveness of urban development. IIED Working Paper. International Institute of Environment and Development. London.

Simone, A. (2010). 'The social infrastructures of city life in contemporary Africa'. The Nordic Africa Institute. Discussion Paper 51. Uppsala.

Thorp, R., Stewart, F., \& Heyer, A. (2005). When and how far is group formation a route out of chronic poverty? World Development, 33(6), 907-920.

Tibaijuka, A. K. (2005). Report of the fact finding mission to assess the scope and impact of operation Murambatsvinva. United Nations: UN Special Envoy on Human Settlements.

Tilly, C., \& Tarrow, S. (2007). Contentious politics. Boulder: Paradigm Publishers.

United Nations. (2015). General assembly resolution - transforming our world: the 2030 agenda for sustainable development. A/RES/70/1. New York: United Nations.

Woolcock, M., \& Narayan, D. (2006). Social capital: implications for development theory, research and policy revisited. In A. Bebbington, M. Woolcock, S. E. Guggenheim, \& E. A. Olson (Eds.), The search for empowerment: social capital as idea and practice at the World Bank (pp. 31-62). Bloomfield: Kumarian Press. 